\title{
Effect of starters on proteolysis of Graviera Kritis cheese
}

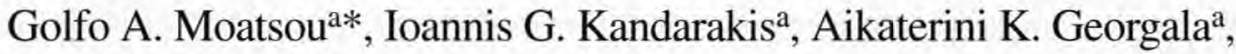 \\ Efstathios S. Alichanidis ${ }^{\mathrm{b}}$, Emmanuel M. Anifantakis ${ }^{\mathrm{a}}$
}

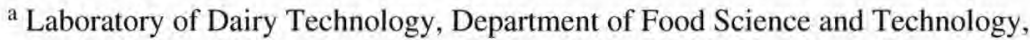
Agricultural University of Athens, Iera Odos 75, 11855 Athens, Greece

${ }^{\mathrm{b}}$ Laboratory of Dairy Technology, Department of Agricultural Science, Aristotle University of Thessaloniki, 54006, Thessaloniki, Greece

(Received 14 May 1998; accepted 30 October 1998)

\begin{abstract}
Four cheesemakings of Graviera Kritis cheese (cheeses A-D) were made from a mixture of ewe's and goat's milk. Three of these were made with mixed cultures of thermophilic + propionic or mesophilic + thermophilic + propionic starters, while the fourth one was made traditionally without starter cultures. The effect of increasing the temperature of ripening was also determined. The $\mathrm{pH}$ 4.4-soluble nitrogen (SN) and trichloroacetic acid (TCA-SN) fractions increased mainly during the warm room ripening. The use of starters caused no significant differences in the ratios of nitrogen fractions of the four mature cheeses (age $>90 \mathrm{~d}$ ), whatever the ripening temperature. Nitrogen fractions were significantly correlated with cheese age. At $180 \mathrm{~d}$ of ripening, the percentage of $\mathrm{pH} 4.4 \mathrm{SN}$ in total nitrogen (TN) was 20.7-22.8\% and that of TCA-SN in TN was 19.1-19.3\%. Polyacrylamide gel electrophoretic (PAGE) results showed that chymosin and plasmin action was intense during the maturation of the cheeses. The proportion of hydrophilic peptides was higher in the water soluble nitrogen (WSN) fraction of the cheeses made with starter cultures at both ripening temperatures. Free amino acids (FAA) were not significantly different in the four types of cheeses, reaching $208-246 \mathrm{mmol} \cdot \mathrm{kg}^{-1}$ after $180 \mathrm{~d}$ of ripening. The changes in total FAA and in the most abundant FAA during the ripening were significantly correlated with cheese age $(r>0.940)$. The ripening at higher temperature increased the main FAA and the total FAA content in all types of cheeses, in particular in the cheese made without starter cultures. (C) Inra/Elsevier, Paris.
\end{abstract}

\section{Graviera Kritis cheese / starter culture / proteolysis}

Résumé - Effet des levains sur la protéolyse du fromage Graviera Kritis. Quatre fabrications de fromages Graviera Kritis ont été réalisées à partir d'un mélange de lait de brebis et de chèvre. Trois d'entre elles ont été ensemencées en levains mixtes, lactiques thermophiles + propioniques ou lactiques mésophiles + thermophiles + propioniques et la dernière a été réalisée traditionnellement, sans levains. Les fractions azotées solubles à $\mathrm{pH} 4,4(\mathrm{pH} 4,4-\mathrm{SN})$ et dans l'acide trichloroacétique $12 \%$

\footnotetext{
* Correspondence and reprints.mg@auadec.aua.gr
} 
(TCA-SN) augmentaient surtout pendant l'affinage en cave chaude. L'utilisation de levains ne provoquait pas de différences significatives des fractions azotées des quatres fromages affinés (âge $>90 \mathrm{j}$ ), quelle que soit la température d'affinage. Les fractions azotées étaient significativement corrélées à l'âge des fromages. Les fractions $\mathrm{pH} 4,4-\mathrm{SN}$ et TCA-SN représentaient respectivement $20,7-22,8 \%$ et 19,1-19,3\% de l'azote total, après $180 \mathrm{j}$ d'affinage. Les résultats des électrophorèses ont montré l'activité de la chymosine et de la plasmine pendant l'affinage des fromages. La proportion de peptides hydrophiles était plus élevée pour les fromages ensemencés en levains aux deux températures d'affinage. Les teneurs en acides aminés libres (AAL) totaux des quatre fromages ne différaient pas significativement et variaient entre 208 et $246 \mathrm{mmol} \cdot \mathrm{kg}^{-1}$ après $180 \mathrm{j}$ d'affinage. L'évolution des principaux AAL et des AAL totaux était significativement corrélée à l'âge des fromages $(r>0,940)$. L'augmentation de la température provoquait une augmentation des AAL totaux et principaux de tous les fromages et de manière plus prononcée pour les fromages fabriqués sans levains. (C) Inra/Elsevier, Paris.

fromage Graviera Kritis / levain / protéolyse

\section{INTRODUCTION}

Graviera Kritis is a Controlled Denomination of Origin hard cheese made from a mixture of ewes' and goats' milk, which is produced in Crete Island of Greece [11]. Its characteristics are described in a previous article by Kandarakis et al. [20].

Graviera Kritis is considered to be a cheese with excellent and distinct flavour characteristics, evolving during ripening. Therefore, the study of its nitrogenous fractions during maturation and the possible correlation of these results with the age of the cheese is of scientific and economic importance. The importance of the nonvolatile water soluble fraction for the characteristic cheese flavour has been proved [23]. For the last few years reverse phase high performance liquid chromatography (RP-HPLC) has appeared to be a suitable method to analyse the water soluble nitrogen (WSN) fractions of different cheese types [e.g. 5-7, 19,31]. The fractions which contribute to cheese flavour contain, in most cases, peptides having a molecular mass $<1000 \mathrm{Da}[4,17]$. The degradation of amino acids, which are the end products of proteolysis during cheese ripening, results in the formation of volatile and non-volatile flavour compounds [1].
The aim of this work was to study, on the one hand, the influence of starters used for Swiss-type cheeses in Graviera Kritis proteolytic profile and, on the other hand, the possibility of improving cheese quality.

\section{MATERIALS AND METHODS}

\subsection{Cheesemaking and sampling}

Cheesemaking and sampling were carried out as described by Kandarakis et al. [20]. In addition, samples were taken only at the end of ripening, from a series of cheeses ripened at $18{ }^{\circ} \mathrm{C}$ (symbolised as 180T d).

The starters used and the corresponding names of the cheeses were as follows:

Cheese A: Streptococcus thermophilus + Lactobacillus helveticus $(1: 1)+$ Propionibacterium freudenreichii subsp. shermanii

Cheese B: Lactococcus Lactis subsp. lactis + Lactococcus lactis subsp. cremoris + Str. thermophilus + Lb. helveticus $(1: 1: 10: 2)+P$. freudenreichii subsp. shermanii

Cheese C: $L c$. lactis subsp. lactis + Lc. lactis subsp. cremoris + Str. thermophilus $+\mathrm{Lb}$. helveticus $(2.5: 2.5: 1: 1)+P$. freudenreichii subsp. shermanii

Cheese D: Without starters 


\subsection{Nitrogen fractions}

\subsubsection{Total nitrogen (TN)}

Total nitrogen was determined according to the Kjeldahl method.

\subsubsection{Nitrogen soluble at $\mathrm{pH} 4.4$ (pH 4.4-SN)}

The method used is described as "METHOD III' for $\mathrm{pH}$ 4.4-SN preparation in 'AIR-FLORA Laboratory Manual' [2], without the step of centrifugation.

\subsubsection{Water soluble nitrogen (WSN)}

One $x \mathrm{~g}$ cheese with $5 \times \mathrm{mL} \mathrm{H}_{2} \mathrm{O}$ were homogenised according to 'METHOD I' for WSN extraction, cited in 'AIR-FLORA Laboratory Manual' [2].

\subsubsection{Nitrogen soluble in $12 \%$ trichloroacetic acid (TCA-SN)}

This was prepared according to 'METHOD I' for TCA-SN fractionation, cited in 'AIR-FLORA Laboratory Manual' [2].

\subsection{Urea-polyacrylamide gel electrophoresis (PAGE)}

Cheese samples and their water soluble extracts (WSN) were analysed by urea-PAGE using the method of Andrews [3] with direct staining using Coomassie brilliant-blue G-250 [9]. Electrophoresis was carried out on a vertical slab unit (LKB vertical electrophoresis unit 2001, Bromma, Sweden) in $14 \times 16 \mathrm{~cm}$ slabs with $1.5 \mathrm{~mm}$ thickness. After destaining with water, the gel slabs were scanned at $590 \mathrm{~nm}$ using a scanning densitometer (Transidyne General Corp., Ann Arbor., MI, USA) linked to a data acquisition and processing system (Nelson Analytical Inc., Paramus, NJ, USA). The results presented are the average of three successive scannings of each lane of the gel slabs.

\subsubsection{Preparation of samples for electrophoresis}

Cheese: One gram of cheese was suspended in $80 \mathrm{~mL}$ stacking gel buffer containing $6 \mathrm{~mol} \cdot \mathrm{L}^{-1}$ urea, $0.1 \mathrm{~mol} \cdot \mathrm{L}^{-1} \beta$-mercaptoethanol and $0.4 \mathrm{~mL}$ tracking dye solution, using a magnetic stirrer. The suspension was kept at $40{ }^{\circ} \mathrm{C}$ for $15 \mathrm{~min}$, and then centrifuged at $3000 \mathrm{~g}$ at $4{ }^{\circ} \mathrm{C}$ for $15 \mathrm{~min}$. The solidified fat layer was discarded and $10 \mu \mathrm{L}$ of the supernatant were used for electrophoresis.

Water soluble nitrogen: Equal volumes of WSN fraction and stacking gel buffer, containing $9 \mathrm{~mol} \cdot \mathrm{L}^{-1}$ urea, $0.1 \mathrm{~mol} \cdot \mathrm{L}^{-1} \beta$-mercaptoethanol and tracking dye, were mixed and $50 \mu \mathrm{L}$ of this sample were used for electrophoresis.

\subsection{Reverse phase high performance liquid chromatography}

RP-HPLC was performed on a two pump system (LKB) fitted to a Nucleosil C 18 column $(4 \times$ $250 \mathrm{~mm}, 5 \mu \mathrm{m}, 30 \mathrm{~nm}$ ) and a guard column of the same material $(4 \times 30 \mathrm{~mm}$; Macherey-Nagel, Duren, Germany). Samples of WSN were applied using a Rheodyne injector, model 7125 , equipped with a $20 \mu \mathrm{L}$ injection loop (Rheodyne Inc., Cotati, CA, USA). Chromatographic conditions were: Solvent A, $0.1 \%(v / v)$ trifluoroacetic acid (TFA) in water; solvent $\mathrm{B}$, a mixture of $60 \%$ acetonitrile, $40 \%$ water and $0.09 \%$ TFA (all by volume). The sample was eluted at room temperature, first with $100 \%$ A for $10 \mathrm{~min}$, then with a gradient of $0-80 \%$ B over 80 and finally with $100 \% \mathrm{~B}$ for $10 \mathrm{~min}$. The flow rate was $0.8 \mathrm{~mL} \cdot \mathrm{min}^{-1}$. The absorbance of the eluate was monitored at $220 \mathrm{~nm}$, using a variable wavelength spectrophotometric detector (LKB, Bromma, Sweden), which was linked to a data acquisition and processing system (Nelson Analytical Inc., Paramus, NJ 07652, USA). Solvents and samples were respectively filtered through $0.45 \mu \mathrm{m}$ Nylon 66 or cellulose acetate filters (Alltech Assoc. Inc., Deerfield, IL, USA).

\subsection{Analysis of free amino acids}

A ternary gradient HPLC system and a fluorescence spectrophotometric detector set at $\lambda$ ex: $330 \mathrm{~nm}$ and $\lambda \mathrm{em}: 464 \mathrm{~nm}$ were used (Scientific System, State College, PA, USA). Free amino acids (FAA) were extracted from cheese samples according to Resmini et al. [28], separated on an ion exchange column, $3 \times 250 \mathrm{~nm} \mathrm{Na}^{+}$form, set at $50^{\circ} \mathrm{C}$ (Pickering Laboratories, Mountain View, CA, USA), and their $o$-phthalaldehyde derivatives were formed using a post-column reactor set at $40{ }^{\circ} \mathrm{C}$ (Pickering Laboratories). Samples were injected through a Rheodyne injec- 
tion port (Model 9125, Rheodyne Inc.). Gradient elution was performed using two sodium citrate buffers: $\mathrm{A}: 0.2 \mathrm{~N} \mathrm{Na}^{+}, \mathrm{pH} 3.15$ and $\mathrm{B} ; 1.0 \mathrm{~N} \mathrm{Na}^{+}$, $\mathrm{pH}$ 7.40. A mixture of $0.1 \mathrm{~N} \mathrm{NaOH}$ and $0.1 \mathrm{~N}$ $\mathrm{NaCl}$ was used as the column regenerator. The column was eluted for $10 \mathrm{~min}$ with buffer $\mathrm{A}$, then with a gradient from $100 \%$ A to $100 \%$ B for $26 \mathrm{~min}$ and finally with $100 \% \mathrm{~B}$ for $24 \mathrm{~min}$. The column was regenerated for $2 \mathrm{~min}$ and then equilibrated with buffer $\mathrm{A}$ for $15 \mathrm{~min}$. The flow rate of the buffers was 0.3 and $0.25 \mathrm{~mL} \cdot \mathrm{min}^{-1}$ of OPA reagent. Quantitation was performed using a data acquisition and processing system (Scientific System, State College, PA, USA).

\subsection{Statistical methods}

One-way analysis of variance (ANOVA) was used to test the differences among the four cheeses (A, B, C and D) at $P \leq 0.05$ at each sampling date. Further testing was carried out by a multiple range tests procedure using the LSD test $(P=0.05)$. The differences between the cheeses which were ripened at $15^{\circ} \mathrm{C}$ during the first 2 months and their pairs ripened at $18{ }^{\circ} \mathrm{C}$ were tested with the $t$-test $(P=0.05)$. The software Statgraphics Plus for Windows v. 5.2 (Manugistics Inc., Rockville, Maryland 20852, USA).

\section{RESULTS}

\subsection{Nitrogen fractions}

The ratio of total proteins to dry matter did not significantly $(P \geq 0.05)$ change during the maturation of all cheeses. After $90 \mathrm{~d}$ of ripening, it was not significantly different for cheeses A, B, C and D and reached 39.33 $\pm 0.29 \%$ (mean \pm standard deviation of the four cheeses). The fraction $\mathrm{pH} 4.4-\mathrm{SN} / \mathrm{TN}$ was not affected by the use of starters, since there were no significant differences between cheeses A, B, C and D at all sampling dates (figure 1 ). It increased significantly $(P \leq 0.05)$ until $90 \mathrm{~d}$ for cheeses A, B and $C$ and until $180 \mathrm{~d}$ for cheese D. At 13 and $30 \mathrm{~d}$ this fraction was respectively two

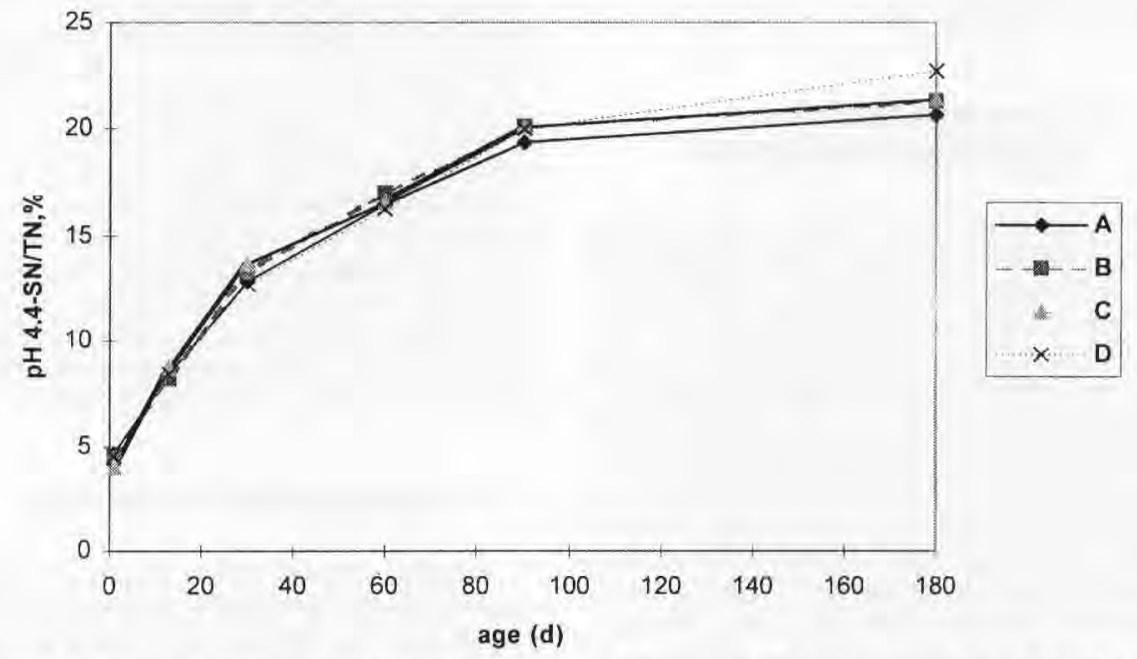

Figure 1. Changes in nitrogen soluble ( $\mathrm{SN}$ ) at $\mathrm{pH} 4.4$ expressed as percentage of total N (TN) during the ripening of Graviera Kritis, made with (A, B, C) or without (D) starters. A: Str. thermophilus + Lb. helveticus $(1: 1)+$ Propionibacterium freudenreichii subsp. shermanii; B: Lc. lactis subsp. Lactis + Lc. lactis subsp. cremoris + Str. thermophilus + Lb. helveticus $(1: 1: 10: 2)+P$. freudenreichii subsp. shermanii; C: Lc. lactis subsp. lactis + Lc. lactis subsp. cremoris + Str. thermophilus + Lb. helveticus (2.5:2.5:1:1) + P. freudenreichii subsp. shermanii; D: Without starters / Sans levains.

Figure 1. Variations de l'azote soluble à $\mathrm{pH} 4,4$ exprimé en pourcentage de l'azote total, pendant l'affinage du Graviera Kritis, fabriqué avec (A, B, C) ou sans levains (D). 
and three times more than that of the 1 st $d$. The fraction TCA-SN/TN showed a similar evolution during the ripening (figure 2). Moreover, it was significantly $(P \leq 0.05)$ lower in cheese $\mathrm{D}$ than in the other cheeses, until $90 \mathrm{~d}$ of ripening. At $30 \mathrm{~d}$, it accounted for more than $80 \%$ of $\mathrm{pH} 4.4-\mathrm{SN} / \mathrm{TN}$ in cheeses A, B and C and only $71 \%$ in cheese D. This difference was still observed at $180 \mathrm{~d}(>90 \%$ for cheeses A, B, C and $84 \%$ for cheese D). Ripening at higher temperature did not affect $\mathrm{pH} 4.4-\mathrm{SN} / \mathrm{TN}$ or TCASN/TN. In all cases the increase of these fractions were significantly correlated with cheese age $(r=0.959-0.989)$.

\subsection{Urea-PAGE}

PAGE profiles during the ripening of Graviera Kritis are shown in figure 3. The hydrolysis of caseins in cheese D was faster than that of cheeses A, B and C. At $13 \mathrm{~d}$ of ripening the residual $\alpha_{\mathrm{s}}$-casein in cheeses
A, B, C and D were respectively $83,77,84$ and $67 \%$ of that of the 1 st d. At $90 \mathrm{~d}$ the respective values were $38,42,42$ and $24 \%$. At $180 \mathrm{~d}$ they were $36,28,40$ and $15 \%$. The ripening at higher temperatures (180T d) promoted $\alpha_{\mathrm{s}}$-casein hydrolysis in cheese C. The respective values were $34,26,19$ and 17 $\%$. The residual $\beta$-casein at $90 \mathrm{~d}$, in cheeses $A$ and $B$, was 70 and $79 \%$, respectively. It was lower in cheeses $\mathrm{C}$ and D (64 and 68 $\%$ ), while in these cheeses the area of $\gamma$ caseins was increased. The respective values at $180 \mathrm{~d}$ were $68,74,52$ and $54 \%$ and at $180 \mathrm{~T} d$ they were $62,62,43$ and $60 \%$.

The area of the WSN PAGE profiles increased during ripening, especially in cheese C. At $90 \mathrm{~d}$ the areas of fractions moving faster than $\alpha_{\mathrm{s}}$-caseins were $253,92,179$ and $246 \%$ of that at the 1 st din cheese A, B, $\mathrm{C}$ and $\mathrm{D}$, respectively. At the same age, the respective areas of the fractions moving slower than $\beta$-casein were $62,144,306$ and $147 \%$.

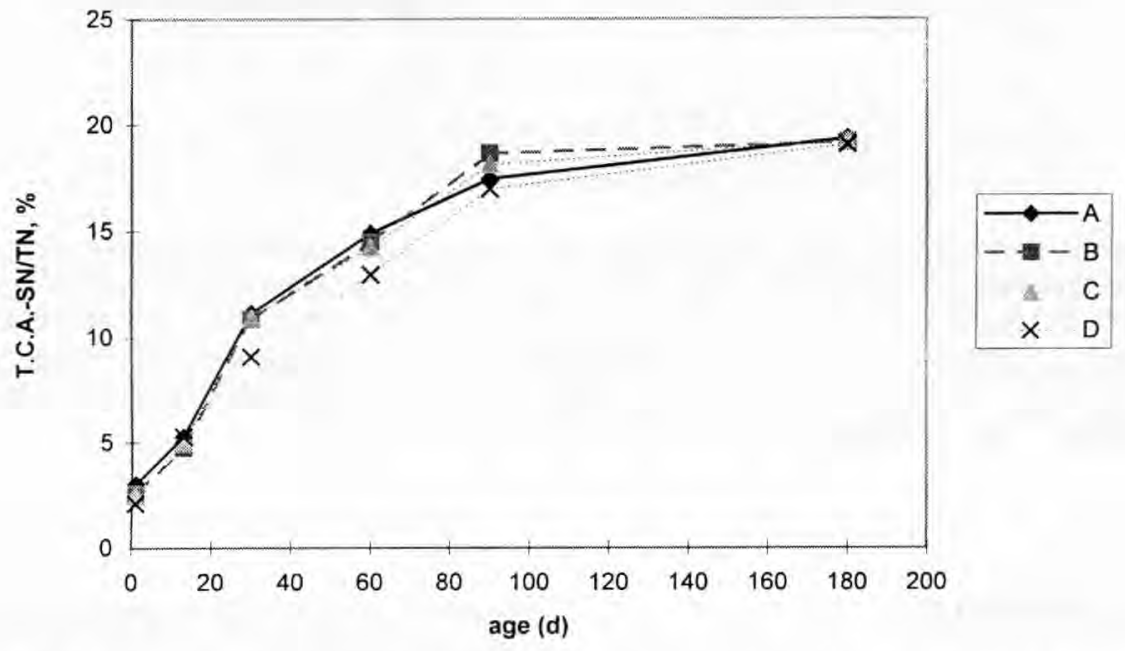

Figure 2. Changes of nitrogen soluble (SN) in $12 \%$ trichloroacetic acid (TCA) expressed as percentage of total $\mathrm{N}(\mathrm{TN})$, during the ripening of Graviera Kritis, made with $(\mathrm{A}, \mathrm{B}, \mathrm{C})$ or without (D) starters. For the corresponding names of cheeses, see figure 1.

Figure 2. Variations de l'azote soluble dans l'acide trichloroacétique à $12 \%$ exprimé en pourcentage de l'azote total, pendant l'affinage du Graviera Kritis, fabriqué avec (A, B, C) ou sans levains (D). A, B, C, D : voir figure 1 . 
A
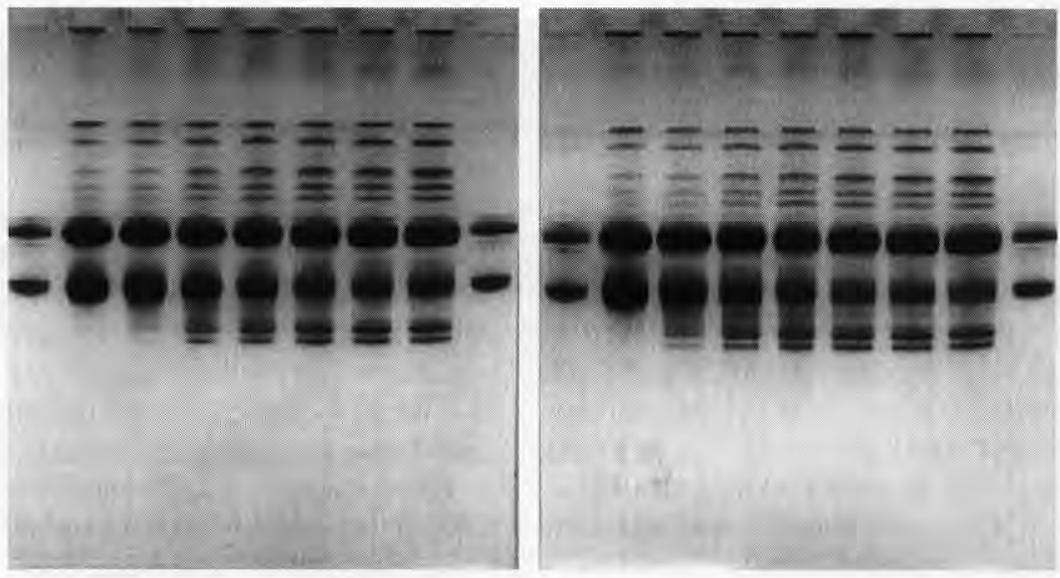

B

C
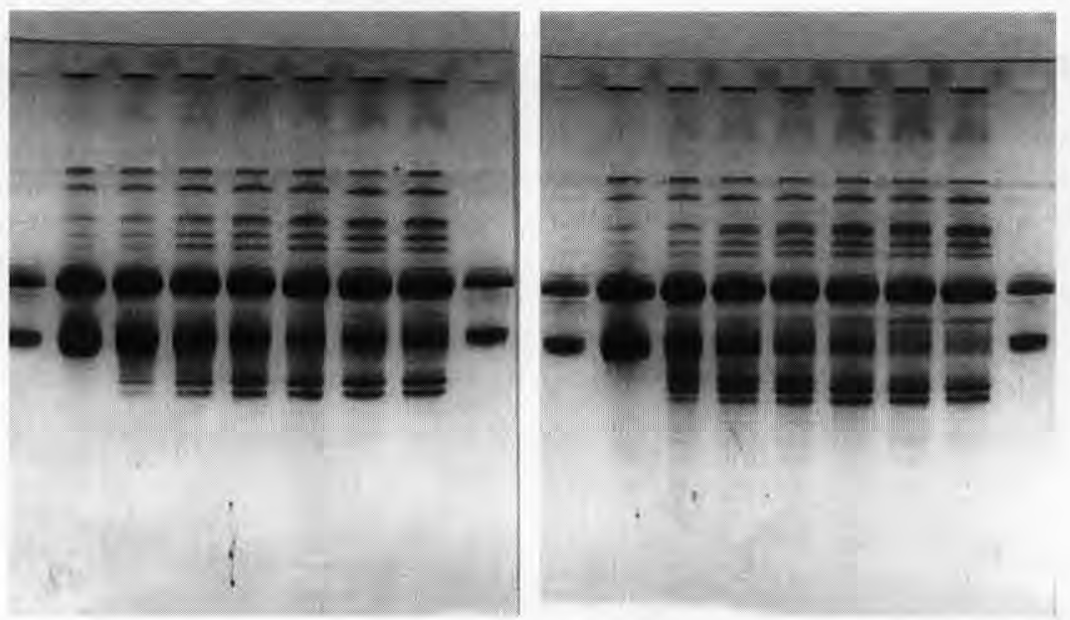

Figure 3. Urea-polyacrylamide gel electrophoretic (PAGE) profiles during the ripening of Graviera Kritis cheeses made with different starters. Lanes 1, 9: whole ovine casein; lanes 2-7: cheese at 1, 13, $30,60,90$ and $180 \mathrm{~d}$ of ripening; lane 8: cheese at $180 \mathrm{~d}$ of ripening, ripened at $18{ }^{\circ} \mathrm{C}$ instead of $15^{\circ} \mathrm{C}$.

Figure 3. Profils uréa-PAGE pendant la maturation du fromage Graviera Kritis, fabriqué avec différents levains. Lignes 1,9: caséine entière de brebis; lignes $2-7$ : fromage de $1,13,30,60,90$ et $180 \mathrm{j}$ d'affinage ; ligne 8 : fromage de $180 \mathrm{j}$, affiné à $18^{\circ} \mathrm{C}$ au lieu de $15^{\circ} \mathrm{C}$.

\subsection{RP-HPLC}

The RP-HPLC WSN profiles of the four cheeses at the 1st and $180 \mathrm{~d}$ of ripening are shown in figure 4. The ratio of $65-95 \mathrm{~min} /$ 0-65 min area of the profiles at the $1 \mathrm{st} \mathrm{d}$ of ripening were $0.37,0.50,0.43$ and 0.31 for cheeses A, B, C and D, respectively. After $180 \mathrm{~d}$ of ripening, the respective values were $0.20,0.25,0.34$ and 0.47 . The ripening decreased this ratio in cheeses A, B and C, but the higher ripening temperatures had a limited effect on this ratio. The respective values at $180 \mathrm{~T} d$ were $0.15,0.25,0.41$ and 0.46 . 


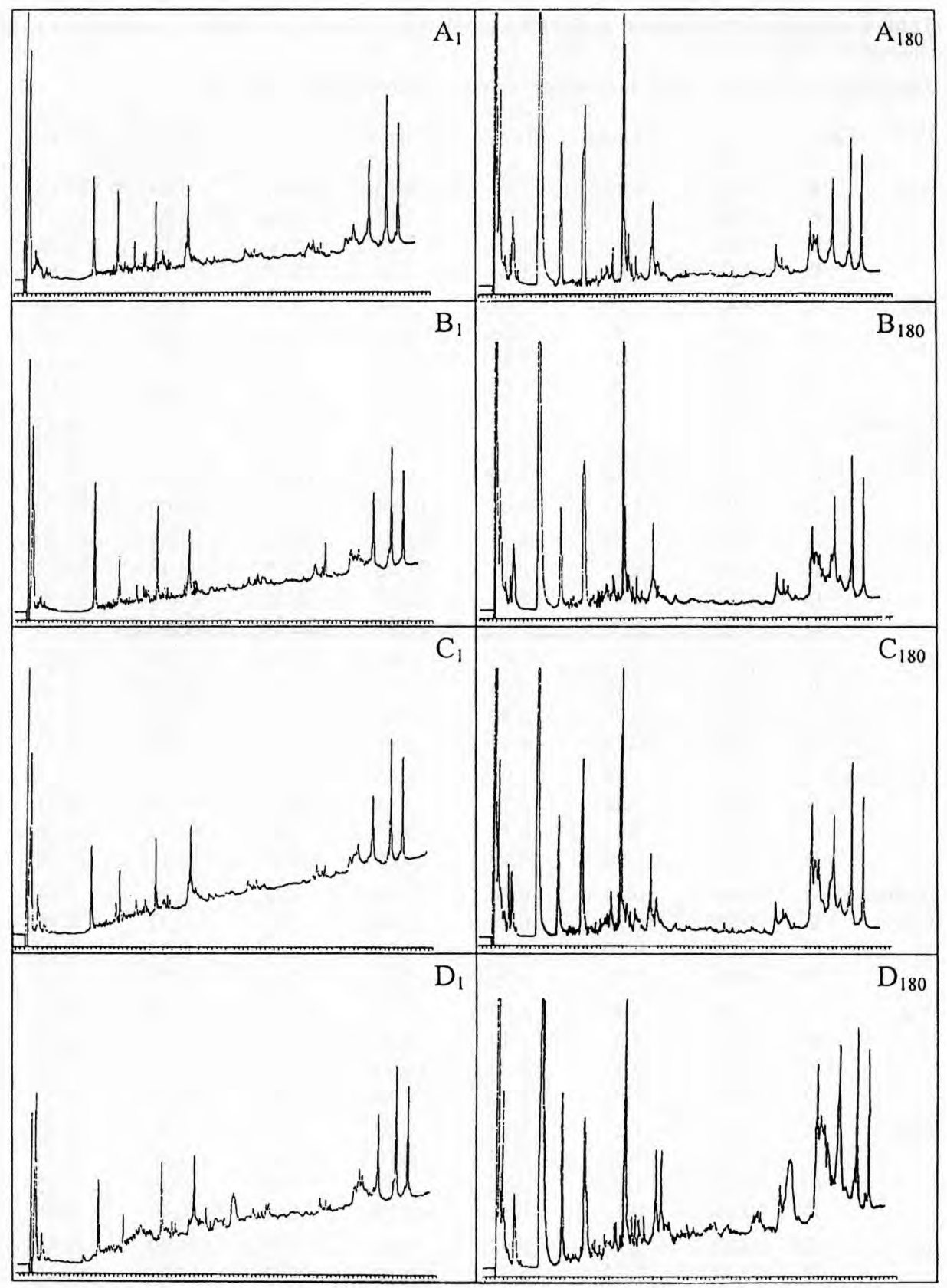

Figure 4. Reverse phase high performance liquid chromatography (RP-HPLC) $\left(\mathrm{A}_{220}\right)$ profiles of water soluble nitrogen (WSN) during the ripening of Graviera Kritis cheeses, made with different starters. $A_{1}, B_{1}, C_{1}, D_{1}=1$ st d; $A_{180}, B_{180}, C_{180}, D_{180}=180 \mathrm{~d}$ of ripening.

Figure 4. Profils RP-HPLC $\left(A_{220}\right)$ du WSN pendant l'affinage du fromage Graviera Kritis, fabriqué avec différents levains. $A_{1}, B_{1}, C_{1}, D_{1}: 1 \mathrm{j} ; A_{180}, B_{180}, C_{180}, D_{180}: 180 \mathrm{j}$ d'affinage. 
Table I. Contents of free amino acids (FAA) $\left(\mathrm{mmol} \cdot \mathrm{kg}^{-1}\right)$ during the ripening of Graviera Kritis cheese.

Tableaux I. Contenu en AAL du fromage Graviera Kritis pendant l'affinage.

FAA Cheese 1 day 13 days 30 days 60 days 90 days 180 days 180 T days

\begin{tabular}{|c|c|c|c|c|c|c|c|c|}
\hline \multirow[t]{4}{*}{ Asp } & A & 0.22 & 1.32 & 2.84 & 5.40 & 6.99 & 9.83 & 11.15 \\
\hline & B & 0.30 & 1.07 & 2.06 & 3.12 & 4.06 & 5.84 & 5.31 \\
\hline & C & 0.19 & 0.96 & 3.29 & 5.28 & 5.60 & 9.11 & 6.76 \\
\hline & D & 0.18 & 0.86 & 1.84 & 3.34 & 5.18 & 8.16 & 9.54 \\
\hline \multirow[t]{4}{*}{ Thr } & A & 0.37 & 1.49 & 2.08 & 3.24 & 3.30 & 4.56 & 5.59 \\
\hline & B & 0.14 & 1.07 & 2.06 & 3.12 & 4.06 & 5.84 & 5.31 \\
\hline & $\mathrm{C}$ & 0.29 & 1.03 & 2.82 & 3.81 & 4.57 & 5.83 & 6.34 \\
\hline & D & 0.15 & 0.70 & 1.02 & 1.70 & 2.23 & 3.68 & 4.12 \\
\hline \multirow{4}{*}{$\begin{array}{l}\text { Ser. Gln. } \\
\text { Asn }\end{array}$} & A & 1.97 & 6.37 & 13.72 & 18.70 & 18.55 & 22.90 & 25.35 \\
\hline & B & 1.26 & 7.00 & 12.23 & 17.27 & 19.64 & 26.79 & 28.23 \\
\hline & $\mathrm{C}$ & 1.72 & 6.26 & 15.32 & 17.93 & 18.38 & 23.33 & 22.72 \\
\hline & $\mathrm{D}$ & 0.93 & 3.54 & 6.05 & 10.84 & 12.39 & 15.09 & 17.50 \\
\hline \multirow[t]{4}{*}{ Glu } & A & 2.12 & 6.63 & 14.33 & 22.73 & 26.13 & 47.83 & 54.00 \\
\hline & B & 1.68 & 6.43 & 12.95 & 21.42 & 27.75 & 52.46 & 56.28 \\
\hline & C & 1.71 & 6.05 & 15.70 & 22.95 & 28.51 & 47.92 & 53.37 \\
\hline & D & 1.23 & 5.07 & 9.66 & 17.61 & 25.28 & 48.69 & 58.43 \\
\hline \multirow[t]{4}{*}{ Gly } & A & 0.27 & 1.31 & 2.92 & 5.00 & 6.09 & 8.29 & 8.22 \\
\hline & B & 0.27 & 1.40 & 3.06 & 5.24 & 6.69 & 8.87 & 9.16 \\
\hline & C & 0.27 & 0.86 & 3.76 & 5.31 & 6.88 & 7.85 & 8.55 \\
\hline & D & 0.28 & 0.78 & 1.44 & 2.94 & 4.57 & 6.60 & 7.75 \\
\hline \multirow[t]{4}{*}{ Ala } & A & 1.76 & 3.58 & 3.01 & 8.46 & 9.73 & 13.56 & 14.16 \\
\hline & B & 0.81 & 2.84 & 4.79 & 7.53 & 9.41 & 13.14 & 15.11 \\
\hline & C & 1.55 & 2.91 & 6.14 & 8.33 & 10.85 & 12.32 & 14.20 \\
\hline & $\mathrm{D}$ & 0.51 & 1.93 & 3.63 & 5.95 & 8.01 & 11.17 & 13.19 \\
\hline \multirow{4}{*}{$\begin{array}{l}\alpha \text {-Aba. } \\
\text { Cys }\end{array}$} & A & 0.04 & 0.24 & 0.76 & 2.73 & 4.21 & 6.26 & 5.01 \\
\hline & B & 0.08 & 0.25 & 0.74 & 1.88 & 2.54 & 3.92 & 4.96 \\
\hline & $\mathrm{C}$ & 0.06 & 0.10 & 0.55 & 1.28 & 2.42 & 2.37 & 2.84 \\
\hline & D & 0.06 & 0.21 & 0.69 & 1.42 & 2.64 & 3.58 & 4.70 \\
\hline \multirow[t]{4}{*}{ Val } & A & 1.00 & 3.42 & 5.03 & 11.18 & 12.75 & 19.96 & 22.53 \\
\hline & B & 0.78 & 4.27 & 8.14 & 12.47 & 14.70 & 23.12 & 24.81 \\
\hline & $\mathrm{C}$ & 0.91 & 3.37 & 8.98 & 11.99 & 14.92 & 19.58 & 21.51 \\
\hline & $\mathrm{D}$ & 0.63 & 2.97 & 5.99 & 9.59 & 12.06 & 18.33 & 21.13 \\
\hline \multirow[t]{4}{*}{ Met } & A & 0.33 & 1.27 & 1.78 & 4.00 & 4.96 & 6.87 & 7.25 \\
\hline & B & 0.24 & 1.20 & 2.49 & 4.14 & 5.44 & 7.66 & 8.23 \\
\hline & $\mathrm{C}$ & 0.28 & 1.00 & 2.84 & 4.39 & 5.86 & 6.49 & 7.45 \\
\hline & D & 0.19 & 0.52 & 1.81 & 3.16 & 4.54 & 6.49 & 7.56 \\
\hline \multirow[t]{4}{*}{ Ile } & A & 0.49 & 2.36 & 3.47 & 9.05 & 10.78 & 15.69 & 17.31 \\
\hline & B & 0.38 & 2.32 & 5.33 & 9.11 & 11.71 & 17.84 & 19.40 \\
\hline & C & 0.41 & 1.81 & 5.95 & 9.21 & 11.89 & 15.91 & 17.50 \\
\hline & D & 0.31 & 1.37 & 2.94 & 5.78 & 8.53 & 13.16 & 16.20 \\
\hline \multirow[t]{4}{*}{ Leu } & A & 1.12 & 4.09 & 5.68 & 12.94 & 14.58 & 23.26 & 24.95 \\
\hline & B & 0.88 & 4.88 & 9.41 & 13.92 & 16.94 & 27.70 & 28.59 \\
\hline & C & 0.93 & 3.92 & 10.01 & 13.64 & 16.77 & 22.93 & 25.17 \\
\hline & D & 0.70 & 3.35 & 6.72 & 11.02 & 13.82 & 22.17 & 25.56 \\
\hline
\end{tabular}


FAA Cheese ${ }^{a} 1$ day 13 days 30 days 60 days 90 days 180 days $180 \mathrm{~T}$ days

\begin{tabular}{|c|c|c|c|c|c|c|c|c|}
\hline Tyr. & A & 0.19 & 0.44 & 0.42 & 0.20 & 0.19 & 0 & 0 \\
\hline \multirow[t]{3}{*}{$\beta$-Ala } & B & 0.20 & 0.13 & 0.08 & 0 & 0 & 0 & 0 \\
\hline & C & 0.17 & 0.27 & 0.25 & 0.17 & 0.08 & 0 & 0 \\
\hline & D & 0.13 & 0.16 & 0.15 & 0.21 & 0.11 & 0 & 0 \\
\hline \multirow[t]{4}{*}{ Phe } & A & 0.43 & 2.06 & 3.17 & 7.13 & 7.84 & 11,37 & 11.57 \\
\hline & B & 0.36 & 2.06 & 4.83 & 7.71 & 9.51 & 13.05 & 13.52 \\
\hline & C & 0.38 & 1.81 & 5.34 & 7.62 & 9.26 & 10.57 & 11.53 \\
\hline & D & 0.29 & 1.47 & 3.55 & 4.21 & 7.73 & 11.36 & 12.56 \\
\hline \multirow[t]{4}{*}{$\gamma$-Aba } & A & 0.09 & 0.31 & 0.41 & 0.65 & 1.02 & 1.30 & 1.56 \\
\hline & B & 0.05 & 0.70 & 1.34 & 1.79 & 1.75 & 2.10 & 4.21 \\
\hline & C & 0.15 & 0.71 & 0.95 & 1.45 & 1.97 & 2.73 & 3.78 \\
\hline & D & 0.08 & 0.93 & 2.15 & 2.45 & 3.10 & 4.03 & 4.60 \\
\hline \multirow[t]{4}{*}{ Orn } & A & 0.36 & 1.82 & 2.56 & 4.83 & 5.96 & 7.88 & 7.91 \\
\hline & B & 0.37 & 1.95 & 3.24 & 4.47 & 5.92 & 8.76 & 8.19 \\
\hline & C & 0.34 & 1.38 & 3.53 & 4.26 & 5.25 & 7.35 & 7.12 \\
\hline & D & 0.27 & 1.18 & 2.16 & 3.79 & 4.81 & 6.21 & 6.51 \\
\hline \multirow[t]{4}{*}{ Lys } & A & 1.38 & 4.37 & 5.90 & 11.91 & 13.59 & 19.82 & 25.98 \\
\hline & B & 0.90 & 4.29 & 8.59 & 12.90 & 15.72 & 27.55 & 29.12 \\
\hline & C & 1.12 & 3.95 & 9.95 & 13.15 & 16.23 & 23.87 & 26.90 \\
\hline & D & 0.69 & 2.82 & 5.88 & 10.32 & 14.05 & 23.38 & 27.48 \\
\hline \multirow[t]{4}{*}{ His } & A & 0.45 & 0.25 & 0.13 & 0.27 & 0.29 & 0.15 & 0.15 \\
\hline & B & 0.25 & 0.74 & 0.79 & 1.14 & 1.12 & 0.73 & 0.64 \\
\hline & C & 0.38 & 0.90 & 1.20 & 1.69 & 2.47 & 2.44 & 2.62 \\
\hline & D & 0.21 & 0.44 & 1.46 & 2.02 & 3.65 & 4.34 & 4.64 \\
\hline \multirow[t]{4}{*}{ Trp } & A & 0.04 & 0.10 & 0.10 & 0.38 & 0.42 & 1.26 & 0 \\
\hline & B & 0 & 0 & 0.17 & 0.18 & 0.57 & 0.81 & 0.39 \\
\hline & C & 0.02 & 0 & 0 & 0.24 & 0.47 & 0 & 0 \\
\hline & D & 0.04 & 0.08 & 0.21 & 0.39 & 0.14 & 1.17 & 0.20 \\
\hline \multirow[t]{4}{*}{ Arg } & A & 0.47 & 0.22 & 0.16 & 0.06 & 0.20 & 0 & 0.07 \\
\hline & B & 0.14 & 0.14 & 0.03 & 0.03 & 0.03 & 0.06 & 0.08 \\
\hline & C & 0.24 & 0.47 & 0.19 & 0.07 & 0.04 & 0.04 & 0.08 \\
\hline & D & 0.04 & 0.20 & 0.15 & 0.06 & 0.05 & 0.08 & 0.13 \\
\hline \multirow[t]{4}{*}{ Total } & A & 13.12 & 41.64 & 68.48 & 128.86 & 147.57 & 220.79 & 242.75 \\
\hline & B & 9.08 & 42.79 & 82.72 & 128.77 & 159.83 & 246.24 & 263.57 \\
\hline & $\mathrm{C}$ & 11.09 & 37.73 & 96.78 & 132.75 & 162.35 & 220.64 & 238.40 \\
\hline & D & 6.98 & 28.88 & 57.50 & 98.80 & 132.91 & 207.69 & 241.60 \\
\hline
\end{tabular}

${ }^{a}$ Starters used and the corresponding names of cheeses are as follows / Levains utilisés : A: Str. thermophilus + Lb. helveticus (1:1) + Propionibacterium freudenreichii subsp. shermanii; B: Lc. lactis subsp. lactis + Lc. lactis subsp. cremoris + Str. thermophilus $+L b$. helveticus $(1: 1: 10: 2)+P$. freudenreichii subsp. shermanii; $C: L c$. lactis subsp. lactis $+L c$. lactis subsp. cremoris + Str. thermophilus $+L b$. helveticus $(2.5: 2.5: 1: 1)+P$. freudenreichii subsp. shermanii; D: Without starters / Sans levains.

\subsection{Free amino acids}

The free amino acid contents of the four Graviera Kritis cheeses during maturation are displayed in table $I$. No citrulline was found. The total percentages of the most abundant FAA (glutamic acid, alanine, valine, isoleucine, leucine, phenylalanine and lysine) in cheeses A, B, C and D at $180 \mathrm{~d}$ were $68.6,70.3,69.4$ and $71.2 \%$, respectively. In cheeses ripened at higher temperature the respective values were 70.3 , 
$70.8,71.4$ and $72.2 \%$. One-way ANOVA of the FAA values for the four cheeses did not show statistically significant $(P \geq 0.05)$ differences at all sampling dates. Analysis by multiple range tests (LSD test, $P=0.05$ ) showed differences among the FAA values of cheeses $B$ and $D(B>D)$, although analysis by $F$-test did not. This contradiction arose from the great variances of FAA mean values. The use of starters did not significantly affect $(P \geq 0.05)$ the FAA content of the cheeses ripened at higher temperature.

The linear correlation coefficients which described the changes of the most abundant FAA during maturation were significantly high $(r=0.953-0.997)$, but the multiplicative equation described more precisely the accumulation process of these FAA than the linear one did. All the FAA shown in table I increased multiplicatively during the maturation with the exception of methionine, histidine and tryptophane. Methionine increased linearly $(r=0.940)$, while the values of histidine and tryptophane were not significantly correlated with the cheese age $(r=0.420$ and $r=0.514$, respectively). Tyrosine, $\beta$-alanine and arginine decreased (negative and very low $r$ ). Ornithine, which is produced from arginine through the urea cycle [21], was increased multiplicatively $(r=0.977)$. The changes of threonine and $\gamma$-aminobutyric acid had lower coefficients of multiplicative correlation $(r=0.905$ and $r=0.892$, respectively) than the other FAA. Glutamic acid increased more rapidly than the other FAA, about 40 times from the 1st to $180 \mathrm{~d}$ of ripening in cheese $\mathrm{D}$ and its concentration was duplicated between 90 and $180 \mathrm{~d}$ (table I).

The FAA contents of the cheeses ripened at $18^{\circ} \mathrm{C}(180 \mathrm{~T} \mathrm{~d})$ were in most cases higher than those ripened at $15^{\circ} \mathrm{C}$. The differences between the values of glutamic acid, alanine, methionine, valine, isoleucine, $\gamma$-aminobutyric acid and lysine at $180 \mathrm{~d}(180 \mathrm{~T}>180)$ were statistically significant and concerned mainly cheese $\mathrm{D}$.

\section{DISCUSSION}

The WSN fraction of Graviera Kritis was complicated, as already shown for profiles of Swiss-type cheeses $[6,7]$. The ratios of $\mathrm{pH}$ 4.4-SN/TN of Graviera Kritis were similar to those referred to the WSN fraction of Emmentaler cheese [32], but the ratios of TCA-SN/TN were higher. Zerfiridis et al. [37] reported higher ratios of WSN/TN but lower ratios of TCA-SN/TN for commercial Gruyère cheese. As expected, the greater part of nitrogen fraction changes occurred during the warm room ripening.

The hydrolysis of $\alpha_{s 1}$-casein in cheese is due to residual chymosin activity which is influenced by cheesemaking conditions [ $[15$, 35]. Collin et al. [10] found that at the end of ripening of Gruyère de Comté, 23.0 \% of $\alpha_{\mathrm{s} 1}$-casein and $39.8 \%$ of $\beta$-casein were still unhydrolysed. In Graviera Kritis, hydrolysis of $\beta$-casein was lower. Hydrolysis of $\beta$-casein in cheese is mainly due to plasmin, because the chymosin and the starter proteinase action are inhibited by the hydrophobic interactions in the region of the molecule, which is susceptible to hydrolysis, due to the salt [15]. The $\mathrm{pH}$ and the salt content of the Graviera Kritis cheese were favourable for plasmin action. In addition, it is expected that the high scalding temperature inactivated plasmin inhibitor and so the activation of plasminogen was faster [16, $35]$. The $\gamma$-caseins were accumulated only in cheese D made without starters. To our knowledge there are no data for plasmin action in ewe's milk and ewe's milk cheeses.

From the study of the main peaks of RPHPLC profiles (figure 4), it was evident that there were few qualitative differences among the WSN fractions of the four types of cheese. It seemed that the quantitative differences were especially more important for cheese D. From these differences and from the data of figures $I$ and 2 and table $I$, it was concluded that the result of the proteolytic activity of non-starter lactic acid bacteria (NSLAB) - which dominated in cheese D 
and grew steadily but more slowly than starter cultures during the ripening $[12,25]$ - appeared later in the traditionally made cheese D. The proteolytic enzymes of lactic acid bacteria act on the large- and mediumsize peptides that arise from casein by the action of rennin and indigenous milk proteases [15]. The microbiological analyses [20] showed that cheese B had a higher number of enterococci at $90 \mathrm{~d}$ than the respective cheeses $A$ and $C$ and cheese D had the higher number of enterococci and mesophilic lactobacilli at $90 \mathrm{~d}$.

In the front area of RP-HPLC profiles hydrophilic and/or small peptides are eluted $[5,19]$. The peaks that are eluted at the rear region of the RP-HPLC profiles are mainly hydrophobic peptides considered to be responsible for the bitter taste of cheese. There was a greater accumulation of peaks in the region 65-95 min of the WSN profile of cheese D. Although none of our cheeses was bitter, it seemed that the mature cheese D had potentially a greater possibility to bitterness than the other three cheeses. The non-bitter large peptides which are produced from casein at the first stage of proteolysis, mainly by the action of rennin, are hydrolysed to bitter ones by the action of the enzymes of starter cultures. The addition of Lactobacillus helveticus, which has great aminopeptidase, dipeptidase, dipeptidyl-peptidase and carboxypeptidase activities, during the cheese manufacture results in the hydrolysis of bitter peptides to nonbitter smaller ones and FAA [22]. It must be noted that according to Tieleman and Warthesen [34], hydrophobicity referring to bitterness may have a different meaning than the hydrophobicity of separation. They consider that the peptide size along with hydrophobicity is likely to be a factor in determining peptide elution order. The percentage of $0-35$ min portion in cheese D was lower at 30 and $60 \mathrm{~d}$ than all the respective values of cheeses made with starters, as also occurred with the respective TCASN/TN fractions.
The middle part of the chromatograms contained few peaks with low chromatographic areas, possibly due to high proteolytic and peptidasic activity of thermophilic lactic acid bacteria [26], which reached high numbers in these cheeses [20]. This activity led obviously to the production of FAA and peptides with molecular mass $<3000 \mathrm{Da}$, which are usually eluted with $\mathrm{CH}_{3} \mathrm{CN}$ concentration $<30 \%[13,19]$, which was in the area of up to $60 \mathrm{~min}$ in our RP-HPLC analyses. From the quantitative analyses of nitrogen fractions (figures 2 and 3 ), it was noted that a great amount of soluble nitrogen consisted in TCA-SN. This fraction includes peptides with two to 20 amino acids [36], which are significantly correlated with cheese flavour $[4,23]$.

The accumulation of large peptides and their hydrolysis to smaller ones and FAA is a dynamic procedure which is difficult to be schematised by studying the main peaks of the chromatograms. Analyses of numerous cheese samples and the study of certain peaks or groups of peaks at many stages of ripening could lead to the correlation of these peaks or groups of peaks with the age of the cheese. The effect of the higher ripening temperature on proteolysis was more intense in cheese $\mathrm{D}$, in which the peaks eluted from $0-35 \mathrm{~min}$ increased at $180 \mathrm{~T} \mathrm{~d}$ at a higher rate than those in $35-65 \mathrm{~min}$.

The FAA contents determined in the Graviera Kritis cheeses were similar to that reported for Swiss-type cheeses or Gruyère de Comté $[8,30,32]$ and for many hard cheeses [13], except the absence of citrulline in Graviera Kritis cheeses. Differences were not statistically significant in spite of the starter addition, especially $L b$. helveticus, in $\mathrm{A}, \mathrm{B}$ and $\mathrm{C}$ cheeses. Lb. helveticus and Lb. delbrueckii subsp, bulgaricus are species with high dipeptidase and aminopeptidase activity [26]. The proteolytic system of $L b$. helveticus is responsible for the onethird of aminopeptidase activity during the maturation of Emmental [27]. However, the high numbers of cheese-milk microflora 
must be taken into account for the interpretation of our results. The higher ripening temperature had a more intense influence on FAA production in cheese $\mathrm{D}$ than in the other three cheeses, as well as on hydrophilic and low molecular mass peptides eluted at the $0-35$ min portion in the WSN RP-HPLC profiles. Total FAA content and the contents of the most abundant of casein amino acids could be indicators for the age of the Graviera Kritis.

Mature cheeses contained high quantities of glutamic acid as well as leucine, lysine and valine. The former dominated and in most cases it was $20 \%$ of total FAA of mature cheeses (table I). Glutamic acid with glutamine are the most abundant amino acid in ewe's $\alpha_{5}$ - and $\alpha$-casein chains. Leucine, lysine and valine also participate greatly in ewes' caseins $[14,29]$. Glutamic acid could play a significant role in the flayour of cheeses. It is known that monosodium glutamate and di- and tri-peptides which have $\mathrm{L}$-glutamic acid as $\mathrm{N}$-end amino acid have an 'umami' (delicious) taste [33], while the presence of $\gamma$-glutamyl peptides could have some additive effect in the complex flavour of Gruyère de Comté [30]. All the cheeses, especially cheese D, contained $\gamma$-aminobutyric acid, which is absent from caseins and comes from the decarboxylation of glutamic acid. When high numbers of certain strains of lactobacilli and enterococci with intense decarboxylation activity are included in the NSLAB population of Gouda cheese, there is an accumulation of biogenic amines [18]. The high content of $\gamma-\mathrm{ABA}$ in cheese $\mathrm{D}$ was accompanied by $\mathrm{CO}_{2}$ production from glutamic acid decarboxylation. This process, along with the activity of wild propionic and heterofermentative bacteria, which are expected to be included in NSLAB, explains the appearance of the openings and splits in cheese D [24, 38]. Histidine and tryptophane make a small contribution to casein composition, which explains their low percentage and their insignificant changes during maturation.
The use of starters in Graviera Kritis did not significantly change the proteolytic profile of ripened cheese, as it also occurred with the organoleptic scores of cheeses [20]. The high numbers and the diversity of NSLAB in the cheeses made without starter cultures, which mainly came from the cheese milk, were capable of causing proteolytic results similar to that of the specific proteolytic starters used in cheeses A, B and C. However, the same results concerning medium- and small-size nitrogenous fractions were accomplished faster in cheeses made with starters. Therefore, damages related to extended ripening could be avoided when starter cultures are used. In addition, the danger of flavour defects such as bitterness could be diminished by the dipeptidasic and aminopeptidasic action of starter cultures, which does not allow the accumulation of bitter peptides.

\section{REFERENCES}

[1] Adda J., Flavour of dairy products, in: Birch G.G., Lindley M.G. (Eds.), Developments in Food Flavours, Elsevier Applied Science, London, 1986, pp. 151-172.

[2] AIR/FLORA Laboratory Manual: Chemical Methods for the Characterization of Cheese Ripening, Work material, AIR-Concerned Action No. 3-CT94-2039, 1997.

[3] Andrews A.T., Proteinases in normal bovine milk and their action on caseins, J. Dairy Res. 50 (1983) 45-55.

[4] Aston J.W., Creamer L.K., Contribution of the components of water soluble fraction to the flavour of Cheddar cheese, N. Z. J. Dairy Sci. Technol. 21 (1986) 229-248.

[5] Belitz H.D., Kaiser K.-P., Monitoring Cheddar cheese ripening by chemical indices of proteolysis. 3. Identification of several high molecular mass peptides, Z. Lebensm. Unters. Forsch. 197 (1993) 118-122.

[6] Bican P., Spahni A., Low molecular-mass nitrogen components in ripening cheese, Lebensm. Wiss. Technol. 24 (1991) 315-322.

[7] Bican P., Spahni A., Proteolysis in Swiss Type cheeses: a high performance liquid chromatography study, Int. Dairy J. 3 (1993) 73-84.

[8] Biede S.L., Hammond E.G., Swiss cheese flavour. I. Chemical analysis, J. Dairy Sci. 62 (1979), 227-237. 
[9] Blakesley R.W., Boezi J.A., A new staining technique for protein in polyacrylamide gels using Coomassie Brilliant Blue G-250, Anal. Chem. 82 (1977) 580-582.

[10] Collin J.C., Berdagué J.L., Dognin-Bergeret M., Grappin R., Affinage et qualité du gruyère de comté. IV. Étude de la protéolyse, Lait 67 (1987) 299-318.

[11] Commission Regulation (EC) No. 1107/96 on the registration on geographical indications and designation of origin under the procedure laid down in article 17 of Council Regulation (EEC) No. 2081/92, Off. J. Eur. Comm. 21 June 1996, No. L 148/1-10.

[12] Crow V.L., Coolbear T., Holland R., Pritchard G.G., Martley F.G., Starters as finishers: starter properties relevant to cheese ripening, Int. Dairy J. 3 (1993) 423-460.

[13] Engels W.J.M., Visser S., Isolation and comparative characterization of components that contribute to the flavour of different types of cheese, Neth. Milk Dairy J. 48 (1994) 127-140.

[14] Ferranti P., Malorni A., Nitti G., Laezza P., Pizzano R., Chianese L., Addeo F., Primary structure of ovine $\alpha_{s,}$-caseins: localization of phosphorylation sites and characterization of genetic variants A, C \& D, J. Dairy Res. 62 (1995) 281-296.

[15] Fox P.F., Proteolysis during cheese manufacture and ripening, J. Dairy Sci. 72 (1989) 1379-1400.

[16] Fox P.F., Law J., Enzymology of cheese ripening, Food Biotechnol. 5 (1991) 239-262.

[17] Jarrett W.D., Aston J.V., Dulley J.R., A simple method for estimating free amino acids in Cheddar cheese, Aust. J. Dairy Technol. 37 (1982) 55-58.

[18] Joosten H.M.L.J., Northolt M.D., Conditions allowing the formation of biogenic amines in cheese. 1. Decarboxylative properties of some non-starter bacteria, Neth. Milk Dairy J. 41 (1987) 259-280.

[19] Kaiser K.-P., Belitz H.-D., Fritsch R.J., Monitoring Cheddar cheese ripening by chemical indices of proteolysis. 2. Peptide mapping of casein fragments by reverse-phase high-performance liquid chromatography, $Z$. Lebensm. Unters. Forsch. 195 (1992) 8-14.

[20] Kandarakis I.G., Moschopoulou E.E., Moatsou G.A., Anifantakis E.M., Effect of starters on gross and microbiological composition and organoleptic characteristics of Graviera Kritis cheese, Lait 78 (1998) 557-568.

[21] Lehninger A.L., Oxidative degradation of amino acids: The urea cycle, in: Principles of Biochemistry, Worth Publishers Inc., New York, 1986, pp. 531-559.

[22] Lemieux L., Simard R.E., Bitter flavour in dairy products. II. A review of bitter peptides from caseins: their formation, isolation and identification, structure masking and inhibition, Lait 72 (1992) 335-382.
[23] McGugan W.A., Emmons D.B., Larmont E., Influence of volatile and nonvolatile fractions on intensity of Cheddar cheese flavour, J. Dairy Sci. 62 (1979) 398-403.

[24] Mocquot G., Reviews of the progress of dairy science: Swiss type cheese, J. Dairy Res, 46 (1979) 133-160.

[25] Peterson S.D., Marshall R.T., Nonstarter lactobacilli in Cheddar cheese: A review, J. Dairy Sci. 73 (1990) 1395-1410.

[26] Pritchard G.G., Coolbear T., The physiology and biochemistry of the proteolytic system in lactic acid bacteria, FEMS Microbiol. Rev. 12 (1993) 179-206.

[27] Prost F., Chamba J.-F., Effect of aminopeptidase activity of thermophilic lactobacilli on Emmental cheese characteristics, J. Dairy Sci. 77 (1994) 24-33.

[28] Resmini P., Hogenboom J.A., Pazzaglia C., Pellegrino L., Free amino acids for the analytical characterization of Grana Padano cheese, Sci. Tec. Latt. Casearia 44 (1993) 7-19.

[29] Richardson B.G., Mercier J.-C., The primary structure of ovine $\alpha$-casein, Eur. J. Biochem. 99 (1979) 285-297.

[30] Roudot-Algaron F., Kerhoas L., LeBars D., Einhorn J., Gripon J.-C., Isolation of $\gamma$-glutamyl peptides from Comté cheese, J. Dairy Sci. 77 (1994) 1161-1166.

[31] Singh T.K., Fox P.F., Hojrup P., Healy A., A scheme for the fractionation of cheese nitrogen and identification of principal peptides, Int. Dairy J. 4 (1994) 111-122.

[32] Steffen C., Eberhard P., Bosset J.O., Ruegg M., Swiss type cheese varieties., in: P.F. Fox (Ed.), Cheese, Chemistry, Physics \& Microbiology, Vol. 2, Major Cheese Groups, 2nd edn., Chapman \& Hall, London, 1993, pp. 88-91.

[33] Sugita Y.-H., Recent developments in umami research, in: Birch G.G., Lindley M.G. (Eds.), Developments in Food Flavours, Elsevier Applied Science, London, 1986, pp. 63-79.

[34] Tieleman A.E., Warthensen J.J., Comparison of three extraction procedures to characterize Cheddar cheese proteolysis, J. Dairy Sci. 74 (1991) 3686-3694.

[35] van den Berg G., Exterkate F.A., Technological parameters involved in cheese ripening. Int. Dairy J. 3 (1993) 485-507.

[36] Yvon M., Chabanet C., Pelissier J.-P., Solubility of peptides in trichloroacetic acid (TCA) solutions, Int, J, Peptide Protein Res. 29 (1989) 166-176.

[37] Zerfiridis G.K., Vafopoulou-Mastrogiannaki A., Litopoulou-Tzanetaki E., Changes during ripening of commercial Gruyère cheese, J. Dairy Sci. 67 (1984) 1397-1407.

[38] Zoon P., Allersma D., Eye and crack formation in cheese by carbon dioxide from decarboxylation of glutamic acid, Neth. Milk Dairy J. 50 (1996) 309-331. 